\title{
Erratum to: Spotting, collecting and documenting negative polarity items
}

\author{
Jan-Philipp Soehn • Beata Trawiński · Timm Lichte
}

Published online: 16 April 2011

(C) Springer Science+Business Media B.V. 2011

\section{Erratum to: Nat Lang Linguist Theory (2010) 28:931-952 DOI 10.1007/s11049-010-9117-x}

Due to an unfortunate oversight, references to the following works were not included in the article by Soehn et al. "Spotting, collecting and documenting negative polarity items" in NLLT 28/4. Most of these publications have been developed between the writing and the publishing of this article.

\section{Additional references}

Richter, Frank, Manfred Sailer, and Beata Trawiński. 2010. The collection of distributionally idiosyncratic items: An interface between data and theory. In Corpora, web and databases: Computer-based methods in modern phraseology and lexicography, eds. Stefaniya Ptashnyk, Erla Hallsteinsdóttir, and Noah Bubenhofer. Vol. 25 of Phraseologie und Parömiologie, 247-262. Baltmannsweiler: Schneider Verlag Hohengehren.

The online version of the original article can be found under doi:10.1007/s11049-010-9117-x.

\section{J.-P. Soehn}

Stäuperle 28, 72108 Rottenburg, Germany

e-mail: jp.soehn@gmail.com

B. Trawiński (凶)

Department of Slavonic Studies, University of Vienna, Spitalgasse 2, Hof 3, 1090 Vienna, Austria e-mail: beata.trawinski@univie.ac.at

T. Lichte

Emmy Noether Project, SFB 441, University of Tübingen, Hausserstr. 11, 72076 Tübingen, Germany e-mail: timm.lichte@uni-tuebingen.de 
Richter, Frank, and Jan-Philipp Soehn. 2006. 'Braucht niemanden zu scheren': A survey of NPI licensing in German. In Proceedings of the 13th international conference on head-driven phrase structure grammar, ed. Stefan Müller, 421-440. Stanford: CSLI Publications.

Sailer, Manfred, and Beata Trawiński. 2006. The collection of distributionally idiosyncratic items: A multilingual resource for linguistic research. In Proceedings of the 5th international conference on language resources and evaluation LREC 2006, Genoa, Italy, 471-474.

Trawiński, Beata, Jan-Philipp Soehn, Manfred Sailer, and Frank Richter. 2008. A multilingual electronic database of distributionally idiosyncratic items. In Proceedings of the XIII EURALEX international congress, eds. Elisenda Bernal and Janet DeCesaris, 1445-1451. Barcelona: Universitat Pompeu Fabra.

Trawiński, Beata, and Jan-Philipp Soehn. 2008. A multilingual database of polarity items. In Proceedings of the sixth international conference on language resources and evaluation LREC 2008. Marrakech: European Language Resources Association (ELRA).

Trawiński, Beata, Manfred Sailer, Jan-Philipp Soehn, Lothar Lemnitzer, and Frank Richter. 2008. Cranberry expressions in English and in German. In Proceedings of the LREC workshop: Towards a shared task for multiword expressions MWE 2008, 35-38. Marrakech: European Language Resources Association (ELRA). 